University of Nebraska - Lincoln

DigitalCommons@University of Nebraska - Lincoln

$1-1-2021$

\title{
Dietary flexibility of Wood Storks in response to human-induced rapid environmental change
}

\author{
Betsy A. Evans \\ Jessica A. Klassen \\ Florida Atlantic University \\ Dale E. Gawlik \\ Florida Atlantic University
}

USDA Wildlife Services, National Wildlife Research Center, Florida Field Station, bevans2014@fau.edu

Follow this and additional works at: https://digitalcommons.unl.edu/icwdm_usdanwrc

Part of the Natural Resources and Conservation Commons, Natural Resources Management and Policy Commons, Other Environmental Sciences Commons, Other Veterinary Medicine Commons, Population Biology Commons, Terrestrial and Aquatic Ecology Commons, Veterinary Infectious Diseases Commons, Veterinary Microbiology and Immunobiology Commons, Veterinary Preventive Medicine, Epidemiology, and Public Health Commons, and the Zoology Commons

Evans, Betsy A.; Klassen, Jessica A.; and Gawlik, Dale E., "Dietary flexibility of Wood Storks in response to human-induced rapid environmental change" (2021). USDA Wildlife Services - Staff Publications. 2500. https://digitalcommons.unl.edu/icwdm_usdanwrc/2500

This Article is brought to you for free and open access by the U.S. Department of Agriculture: Animal and Plant Health Inspection Service at DigitalCommons@University of Nebraska - Lincoln. It has been accepted for inclusion in USDA Wildlife Services - Staff Publications by an authorized administrator of DigitalCommons@University of Nebraska - Lincoln. 


\title{
Dietary flexibility of Wood Storks in response to human-induced rapid environmental change
}

\author{
Betsy A. Evans ${ }^{1,2}$. Jessica A. Klassen ${ }^{1}$. Dale E. Gawlik ${ }^{1,3}$ \\ Accepted: 14 October 2021 \\ () The Author(s), under exclusive licence to Springer Science+Business Media, LLC, part of Springer Nature 2021
}

\begin{abstract}
Human-induced rapid environmental change (HIREC) has altered landscape processes and negatively impacted many species globally. Some of the most dramatic changes have been in wetlands where flows have been disrupted, and new wetlands have been created to retain runoff. In response to disrupted natural wetland conditions, Wood Stork (Mycteria americana) populations in South Florida have significantly declined over the past several decades. Despite the well-documented sensitivity of Wood Storks to natural wetland conditions, Wood Storks are often observed foraging in roadside created wetlands; however, the availability of prey in created wetlands is currently unknown. We sampled natural and created wetlands to determine aquatic fauna available for foraging Wood Storks. To determine prey use, we collected food boluses from Wood Storks in both natural wetland and urban landscapes. Historical studies found nonnative fish were absent in Wood Stork diet prior to the dominance of created wetlands in the landscape; however, we found nonnative fish frequently in both created wetlands and boluses. Furthermore, urban nesting Wood Storks consumed large-bodied prey species that were more characteristic of created wetlands whereas Wood Storks nesting in natural wetlands consumed large-bodied prey more characteristic of natural wetlands. Overall, Wood Storks consumed prey that were more similar to the fish community in created wetlands than those in natural wetlands. These dietary patterns suggest that Wood Storks have behavioral plasticity in both foraging habitat and prey use to cope with HIREC. Conservation efforts for species existing in both natural and urban habitats should consider the importance of novel prey and foraging habitats, as they may assist in sustaining populations in a rapidly changing world.
\end{abstract}

Keywords Created wetlands $\cdot$ Diet flexibility $\cdot$ HIREC $\cdot$ Natural wetlands $\cdot$ Wood Storks

\section{Introduction}

Human-induced landscape changes are negatively impacting species globally (Baronsky et al. 2011). While all species deal with some form of environmental uncertainty, human manipulation of the environment has created novel conditions and more rapid rates of environmental change than many species have been exposed to in their evolutionary past (Palumbi

Betsy A. Evans

bevans2014@fau.edu

1 Department of Biological Sciences, Florida Atlantic University, 777 Glades Rd, Boca Raton, FL 33431, USA

2 U.S. Department of Agriculture, Wildlife Services, National Wildlife Research Center, Florida Field Station, 2820 East University Avenue, Gainesville, FL 32641, USA

3 Harte Research Institute for Gulf of Mexico Studies, Texas A\&M University Corpus Christi, 6300 Ocean Drive, Corpus Christi, TX 78412, USA
2001; Sih et al. 2011; Wong and Candolin 2015). These rapid, human-caused changes are referred to collectively as humaninduced rapid environmental change (HIREC), and include habitat loss and degradation, introduction of nonnative species, pollution, overharvesting, and climate change (Sih et al. 2011).

Whereas most species struggle to cope with these changes, other species remain stable or even thrive in response to HIREC (Lopéz-Sepulcre and Kokko 2012; Wong and Candolin 2015). The options for species responding to HIREC include adaption through genetic change, dispersal, or change through phenotypic plasticity (Williams et al. 2008; Wong and Candolin 2015). Given the limited opportunities for dispersal or adaptation (Sih 2013; Snell-Rood 2013; Wong and Candolin 2015), phenotypic plasticity can act as a key mechanism through which species deal with rapid environmental change (Sol et al. 2013) and is often the first indicator of a species response to HIREC (Wong and Candolin 2015). The ability to readily modify behavior increases the probability that at least some individuals will successfully reproduce and survive in habitats with high environmental 
variation (natural or human-induced), leading to a strong selection for behavioral plasticity (Wong and Candolin 2015).

There are several measures that quantify behavioral responses to HIREC. Behavioral flexibility can be expressed as changes in habitat use (Van Houtan et al. 2007), phenology (Gienapp 2012), communication (Rosenthal and Stuart-Fox 2012), or even diet (Brousseau et al. 1996; Klassen and Gawlik 2018). Given that many species are food limited (Lack 1954), a dietary shift can act as an indicator for behavioral flexibility in a population. Whereas HIREC may lead to species encountering dietary opportunities that they have not encountered in their evolutionary past, choosing a novel prey species may be maladaptive. A maladaptive response may include consuming prey items of low quality (Grémillet et al. 2008) or prey high in toxins (Oaks et al. 2004), whereas an adaptive dietary response may include new high quality prey species (Cattau et al. 2016) or anthropogenic foods ( Ruffino et al. 2014) that are more abundant or predictable than natural food sources.

Wood Storks (Mycteria americana; hereafter referred to as "storks") in South Florida provide an opportunity to study a food limited species and its dietary response to HIREC. As tactile foragers, storks require areas with a high density of prey that can be easily captured to successfully forage and initiate nesting (Kahl 1964; Ogden 1994). The Everglades, a seasonally pulsed subtropical wetland, is characterized by wet and dry seasons which together provide the mechanism to produce high prey concentrations (Kahl 1964; Kushlan 1976; Loftus and Kushlan 1987; DeAngelis et al. 2010). Unpredictable increases in water levels during the dry season can cause prey to disperse out of concentrated pools. These reversals reduce prey availability for storks, which require certain water depths to forage optimally (Kahl 1964; Gawlik 2002). Because storks require specific foraging conditions to meet the high caloric demands of nesting, prey availability is considered a limiting factor (Frederick and Spalding 1994; Gawlik 2002).

In response to habitat loss and degradation of the Everglades, stork populations in South Florida declined and the species was listed as Endangered in 1984 (USFWS 1996). Along with the loss and degradation of the natural wetland system, created wetlands were introduced to the South Florida landscape, further altering natural wetland hydroperiods (King et al. 2004), and in some cases, creating deep water habitats that were previously uncommon (Gunderson and Loftus 1993). In response to these human-induced landscape changes, storks reduced nesting in coastal areas and shifted the onset of their nesting from November to February, giving adults limited time to fledge young before the onset of the wet season when prey are again dispersed (Frederick et al. 2009). In years when the wet season begins early, or dry season rain events reverse the drying pattern and raise water levels, nestlings either do not fledge (Ogden 1994; Nuttle 1997) or have low survival (Borkhataria et al. 2012). Consequently, natural wetland colonies in South Florida have had minimal stork recruitment (Borkhataria et al. 2012). However, in recent decades storks have expanded their range northward and increased nesting in urban areas in South Florida (Gawlik 2000). In 2014, Wood Storks were down-listed to Threatened as the total breeding population increased (USFWS 2015). In South Florida, the core area of stork nesting, the breeding population has not reached standard recovery levels (USFWS 2014).

Despite the well-documented sensitivity of storks to changes in foraging conditions and human disturbance (Rodgers and Smith 1995; Rodgers and Schwikert 2002), storks are often observed foraging in roadside created wetlands such as canals and swales, suggesting these features provide foraging habitat. It is not clear the extent to which created wetlands may be replacing natural wetlands for stork use. These anthropogenic features may provide more stable hydroperiods, higher secondary productivity through nutrient subsidies, and open edges for foraging where fish seek refugia from deep water predators (Fidorra et al. 2016). Additionally, created wetlands are thought to be the mechanism in which nonnative fish populations are introduced and spread into the natural wetland system (Shafland et al. 2008; Kline et al. 2014). Canals in particular are favorable habitat for largebodied and nonnative fishes because of deep water and warmer temperatures, thus providing refugia during drought and cold stress conditions (Shafland and Pestrak 1982; Trexler et al. 2000; Schofield et al. 2010). Moreover, urban nesting storks in South Florida increase their dietary breadth during poor natural wetland conditions (Evans and Gawlik 2020). This suggests that there is available foraging habitat outside of the natural wetland system which may provide storks with more predictable prey availability when conditions in natural wetlands are unpredictable.

Since storks are limited by the timing, abundance, and availability of food, a shift in their diet could indicate some form of behavioral plasticity in response to HIREC. A recent study found that storks in South Florida were consuming large-bodied (e.g., centrarchids and ictalurids) and nonnative fish species (e.g., cichlids; Klassen and Gawlik 2018). This differed from an earlier prey composition study (Ogden et al. 1976) in which storks were found to consume primarily small-bodied $(<2 \mathrm{~cm})$, native wetland fish. At the time of the early study, created wetlands were not as prevalent as they are today, and fewer nonnative fishes were documented in South Florida. Klassen and Gawlik (2018) proposed that storks may have shifted to using created wetlands during the breeding season, given the presence of large-bodied and nonnative species in the diet. To test this hypothesis, we: 1) quantified the use of prey from created wetlands and 2) determined the degree of diet differences between storks that nest in the historical, natural wetland landscape and storks that nest in the urban landscape. Specifically, we predicted that prey composition in created wetlands will most resemble the prey consumed by storks, and that large-bodied and nonnative fishes are most characteristic of the deep water created wetlands (i.e. permanently inundated stormwater ponds and canals). Furthermore, we expected that storks nesting in urban 
areas would most likely consume prey that was most similar to what was found in created wetlands.

\section{Methods}

\section{Study area}

We conducted our study in the freshwater Everglades and adjacent urban areas in South Florida from 2014-2017. Wetland vegetation includes sawgrass (Cladium jamaicense), spikerush (Eleocharis spp.), maidencane (Panicum hemitomon), bladderwort (Utricularia spp.) and water lily (Nymphaea odorata). Tree islands, where storks nest, are dominated by willow (Salix spp.), cypress (Taxodium spp.), and pond apple (Annona glabra). The Everglades system borders expansive urban development on its eastern edge. Study sites included similar native wetland and tree island community vegetation in addition to nonnative vegetation such as hydrilla (Hydrilla verticillata), water hyacinth (Eichhornia crassipes), water lettuce (Pistia stratiotes), Brazilian pepper (Schinus terebinthifolius), and Australian pine (Casuarina spp.). Hydrologic conditions were variable during the study period. 2014 and 2015 began with moderate water levels with a steady water level recession; however, there were increases in water levels throughout the breeding season which allowed stork prey to disperse from concentrated pools. In 2016 South Florida experienced unseasonably high dry season rainfall with a minimal water level recession, which resulted in few pools of concentrated prey for foraging storks. Conversely, in 2017 the region had below average dry season rainfall, allowing for a steady water level recession throughout the dry season, resulting in pools of concentrated prey to support breeding storks.

\section{Prey use}

We collected food boluses (stomach regurgitations) from nestling storks at two long-used natural wetland nesting colonies (Paurotis Pond: 25.2817, -80.8015 and Tamiami West: 25.7557, -80.5443) in Everglades National Park during the 2014-2017 breeding seasons (approximately March through June). Paurotis Pond is surrounded by brackish water near the southern tip of Florida whereas Tamiami West is located $\sim 60 \mathrm{~km}$ north in the freshwater interior of the Everglades. We did not collect boluses from Tamiami West in 2016 because no storks nested in the colony, likely because of suboptimal hydrologic conditions in the natural wetland system. In addition to natural wetland colonies, we collected boluses at three urban colonies during the 2015-2017 breeding seasons. Griffin (26.0637, -80.3665) and Sawgrass (26.1498, -80.3377) colonies are located within urban Broward County and BallenIsles colony $(26.8301,-80.1092)$ is located further north within urban Palm Beach County.
We visited each colony one or two times per week during the breeding season. Nestlings often regurgitate in the presence of humans; however, in the event a targeted nestling did not voluntarily regurgitate, we gently massaged its throat to encourage regurgitation. Once a nestling regurgitated, we left an approximately equal mass of small fish in the nest to compensate for loss of bolus contents. Storks readily consume regurgitated fish from the nest bowl (BAE personal observation), so our collection methods did not reduce the amount of food provided to nestlings. The majority of boluses were collected from chicks between 7 and 28 days with only $12 \%$ of boluses collected from chicks $>$ 28 days (i.e. 29-70 days). For the duration of the sampling trip, we placed all bolus contents in a labeled plastic bag stored on ice. After collection, samples were poured through a 0.6 micrometer mesh net and rinsed with water. We identified all prey to the lowest possible taxonomic level (usually species), weighed to the nearest $0.01 \mathrm{~g}$, measured to the nearest millimeter, and noted whether each piece represented a partial or whole prey species. Body length is reported as standard length for fish species and total length for invertebrates.

\section{Natural wetland prey availability}

To determine prey availability to storks in natural wetlands, we sampled aquatic fauna during the stork breeding season across the Everglades as part of a companion study. The companion study measured dry season aquatic prey composition and biomass density in wetlands annually since 2005 (see Botson et al. 2016). Prey were sampled with a throw trap, a $1-\mathrm{m}^{2}$ box with mesh sides and an open top and bottom (Jordan et al. 1997). Throw traps are the preferred method of sampling fish in vegetated habitats found in the Everglades (Jordan et al. 1997), allowing for an accurate estimate of the density of prey available to storks.

\section{Created wetland prey availability}

We sampled four created wetland types: swales, canals, permanently inundated stormwater ponds, and ephemeral stormwater ponds. We randomly identified created wetlands from a digitized map and selected them after to determine whether they were accessible to foraging storks. To account for the diversity of potential stork foraging habitat outside the natural wetland system, we sampled aquatic fauna along major roadways within the three major landscape cover types (herbaceous wetland, forested wetland, urban) in the region. Within each major landscape cover type, we sampled three sites for each created wetland type, resulting in a total of 36 sites.

No single sampling gear is effective across the wide structural range of created wetlands that were part of the study. Thus, we used throw traps to sample ephemeral ponds and swales and used modified Gee's G-40 minnow traps to sample permanently inundated ponds and canals. The trap modification was to increase the opening size to a $10-\mathrm{cm}$ tall vertical oval allowing for the capture 
of wide-bodied fish that might inhabit the deep water. Minnow traps were arranged as an array that bisected a canal (short axis) or pond. Each array began and ended with a trap placed near the shoreline to capture fish in shallow water where storks would most likely forage. In the interior of a pond or canal, the array contained a series of three equally spaced traps suspended vertically from the bottom to the surface, with the number of traps determined by the depth of the canal or pond. For instance, deep canals or ponds (depths $>1.5 \mathrm{~m}$ ) consisted of three traps: one just below the water surface, one resting on the substrate, and one equal distances between the two traps. For intermediate canal or pond depths (1.0 to $1.5 \mathrm{~m}$ ), each trap series included two traps: one just below the water surface, and one resting on the substrate. For shallow canal or pond depths $(<1.0 \mathrm{~m})$, each trap series included only one trap resting on the substrate. To allow time for aquatic fauna to enter the traps, we left the minnow traps in place for $\sim 24 \mathrm{~h}$ before we collected and removed trap contents.

For all samples, we transferred captured fauna directly to jars containing a solution of water and tricaine methanesulfonate (MS 222; $300 \mathrm{mg}-\mathrm{L})$. We identified all prey to the lowest possible taxonomic level (usually species), weighed to the nearest $0.01 \mathrm{~g}$, and measured to the nearest millimeter. Body length is reported as standard length for fish species and total length for invertebrates.

\section{Sampling method efficacy}

To test for sampling bias between the two trap types, we paired throw traps with modified minnow traps at 10 random sites in natural wetlands during the 2017 breeding season. Both throw trap and minnow trap sampling sites were in areas of shallow water and sparse vegetation. We placed minnow traps at least $10 \mathrm{~m}$ from throw trap sampling sites to avoid any disturbance. We left minnow traps in place for $\sim 24 \mathrm{~h}$ before we collected and removed trap contents.

We used PRIMER 7 to conduct multivariate techniques derived from Bray-Curtis similarities to determine sampling similarity (Clarke and Gorley 2015). We calculated total biomass of each prey species found within each sample point. Each sample point is representative of an array of throw trap or minnow-trap samples at a given random site in the natural wetland type. We used a square-root transformation which allows for a greater contribution of rare species (Clarke and Green 1988). We ran a one-way analysis of similarities test (ANOSIM) to determine if prey composition varied between sampling methods. ANOSIM analyses include an R statistic which is based on rank similarities. An R statistic value near zero suggests that similarities are the same within and among groups whereas an $\mathrm{R}$ statistic value near one suggests that samples within groups are more similar to each other than to samples in other groups (Clarke and Gorley 2015). Since the $p$-value can be strongly influenced by the number of permutations required by the analysis, both the $\mathrm{R}$ statistic and $p$-value should be used when analyzing results (Clarke and Gorley 2015). Additionally, we used non-metric multidimensional scaling (NMDS) plots derived from a Bray-Curtis dissimilarity matrix to provide a visual representation of the prey composition dissimilarities or similarities between sampling methods. The overall low $\mathrm{R}$ statistic (ANOSIM Global $R=0.02)$ and corresponding $p$-value $(P$ $=0.31$ ) suggest that prey composition did not vary significantly between minnow trap and throw trap samples within the natural wetland (Supplementary Materials, Fig. S1).

We also generated rarefaction curves to investigate bias in our sampling methods (e.g., Ishiyama et al. 2016). We used extrapolation of a sample-based rarefaction curve where the plateau of the curve represents estimated species richness (Cowell et al. 2012; Chao et al. 2014). A large difference between the observed and estimated species richness suggests that the sampling method was inadequate with a high probability of species bias. We generated rarefaction curves using the $i N E X T$ package (Hsieh et al. 2016) in R 3.4.2 (R Development Core Team 2017). The difference between the observed and estimated species richness within each wetland type was small across all wetland types, with each sampling method accounting for $>80 \%$ of the estimated species richness within a particular wetland type (Supplementary Materials, Fig. S2). This suggests that the sampling methods we used were acceptable for capturing fish communities across wetland types in our study area despite the different sampling methods.

\section{Statistical analyses}

To determine prey composition of aquatic fauna consumed by storks, we used the same nonparametric multivariate techniques as previously described. To analyze prey consumption patterns at the colony level and improve visual representation in NMDS plots, we combined bolus samples collected from the same colony on the same date. Each sample point was representative of prey communities consumed by storks spatially (colony location) and temporally (sample date).

To determine prey available to storks from created and natural wetlands, we used similar nonparametric multivariate techniques. For natural wetland sites, we included only throw trap samples that occurred within $74 \mathrm{~km}$ of each colony, the maximum foraging distance observed for storks in our study area (Herring and Gawlik 2011). For created wetland types, we included all sites regardless of distance from colony, as our sample size was limited $(n=36)$ and we were restricted geographically to sites near major roadways. However, four of the five colonies sampled had created wetland study sites well within the $74 \mathrm{~km}$ foraging radii. We also found that within each created wetland type (i.e. canals, permanently inundated ponds, ephemeral ponds, and swales), aquatic fauna assemblages did not vary geographically (urban, forested wetland, herbaceous wetland), supporting the inclusion of all sampled created wetlands. We only included throw trap and minnow trap samples from created and natural wetlands that were collected within the 
same data range as bolus samples for each year. To analyze prey available in natural wetlands and improve visual representation in NMDS plots, we combined samples from the same site on the same day. Similarly, to analyze prey available in created wetlands and improve visual representation in NMDS plots, we combined created wetland samples by site and year.

To determine how stork prey consumption relates to prey availability in created and natural wetlands, we used NMDS plots to examine the overlap of stork prey and prey available in created and natural wetlands. We used an ANOSIM analysis to determine if there was a statistical difference among bolus, natural wetland, and created wetland samples. If there was a statistical difference, we performed a SIMPER analysis to determine which prey species were driving the differences between samples. In addition, we used a Kruskal-Wallis test to compare prey lengths found within stork boluses to aquatic fauna prey lengths available in natural and created wetlands ( $R$ Development Core Team 2017).

To compare prey consumption of natural wetland and urban nesting storks we used the same multivariate techniques described previously. Additionally, we used a Wilcoxon rank-sum test to compare prey lengths between storks nesting in urban and natural wetlands ( $\mathrm{R}$ Development Core Team 2017). The effect of the values reported are mean \pm SE.

\section{Results}

We collected a total of 753 boluses from stork nestlings (Tamiami West $n=164$, Paurotis Pond $n=190$, BallenIsles $n=172$, Griffin $n=177$, and Sawgrass $n=50$ ) from the 2014-2017 nesting seasons. Average prey length (mean \pm SE) across colonies was $5.0 \pm 0.4 \mathrm{~cm}$ and average prey weight (mean $\pm \mathrm{SE}$ ) was $6.2 \pm 0.4 \mathrm{~g}$. The low global $R$ statistic (ANOSIM Global $R=0.12$ ) suggested only minor prey composition differences across colonies $(P=0.001)$. Similarly, a low global $\mathrm{R}$ statistic (ANOSIM Global $R=0.01)$ implied only minor prey composition differences across years $(P=0.001)$.

The most commonly consumed prey items by storks were spotted sunfish (Lepomis punctatus), African jewelfish (Hemichromis letourneuxi), warmouth (L. gulosus), mosquitofish (Gambusia holbrooki), dollar sunfish (L. marginatus), and sailfin molly (Poecilia latipinna), accounting for $71 \%$ of all prey items consumed (Supplementary Materials, Table S1). Species contributing most to the overall prey biomass found within stork boluses included spotted sunfish, warmouth, African jewelfish, dollar sunfish, brown bullhead (Ameiurus nebulosus), and grass carp (Ctenopharyngodon idella), accounting for $46 \%$ of total prey biomass. Nonnative species accounted for $17 \%$ of all prey items and $14 \%$ of the total biomass found within stork boluses. The range of nonnative species in stork diet varied by colony and year with the most nonnative prey species (64\%) found within boluses from Paurotis Pond in 2016. Large-bodied (e.g., centrarchids and ictalurids) fish species accounted for $65 \%$ of all prey items and $88 \%$ of the total biomass (see Supplementary Materials, Table S1 for species categorized as nonnative or large-bodied).

To characterize prey available to storks in natural wetlands, we used a total of 310 throw traps $(2014 n=108,2015 n=4,2016$ $n=107,2017 n=91$ ). The low sample size in 2015 did not bias prey availability in natural wetlands as aquatic faunal communities as the global $R$ statistic (ANOSIM Global $R=0.12$ ) indicated similarity across samples with only minor differences $(P$ $=0.001)$. Average prey length across natural wetlands was 1.60 $\pm 0.01 \mathrm{~cm}$ and average prey weight was $0.16 \pm 0.01 \mathrm{~g}$. Aquatic faunal communities in natural wetlands were similar (ANOSIM Global $R=0.09)$ within the foraging radii $(74 \mathrm{~km})$ of all colonies with only minor differences $(P=0.001)$. The most common species in natural wetland samples were grass shrimp (Palaemonetes paludosus), bluefin killifish (Lucania goodei), mosquitofish, and least killifish (Heterandria formosa), accounting for $36 \%$ of all prey items (Supplementary Materials, Table S1). Grass shrimp, crayfish (Procambarus spp.), bluefin killifish, mosquitofish, sailfin molly, and spotted sunfish, contributed $53 \%$ to overall prey biomass. Nonnative species accounted for $0.5 \%$ of all prey items and contributed 3\% to the overall biomass. Large-bodied prey species (i.e. centrarchids and ictalurids) accounted for $1 \%$ of all prey items and contributed $11 \%$ to the overall biomass.

A total of 51 throw traps and 1,259 minnow traps were used to characterize aquatic fauna available to storks in created wetlands from 2014-2016. More minnow traps were necessary at permanently inundated created wetlands as these sites are larger and deeper and the sampling method relies on prey species actively encountering the trap. Created wetlands were not sampled during the 2017 season; however, during sampled years, prey composition of sites was similar with very minor differences (ANOSIM Global $R=0.01, P=0.02$ ). Average prey length across created wetlands was $2.2 \pm 0.01 \mathrm{~cm}$ and average prey weight was 0.6 $\pm 0.1 \mathrm{~g}$. Prey composition was similar across months sampled with minor differences (ANOSIM Global $R=0.01, P=0.001$ ). The most common species found in created wetlands were least killifish, grass shrimp, mosquitofish, and tadpoles (Anura spp.), accounting for $44 \%$ of all prey items (Supplementary Materials, Table S1). Mayan cichlids (Cichlasoma urophthalmus), African jewelfish, bowfin (Amia calva), mosquitofish, crayfish, and warmouth, contributed $43 \%$ to the overall biomass. Nonnative species contributed to $5 \%$ of the available prey and accounted for $33 \%$ of the available biomass in created wetlands. The majority of nonnative species were found in permanently inundated ponds and canals (95\%). Large-bodied prey contributed to $80 \%$ of available prey and accounted for $65 \%$ of the overall biomass. Similarly, large-bodied prey were found most frequently in permanently inundated ponds and canals having the most large-bodied prey items (99\%) of all created wetland types.

Overall, prey composition differed significantly between stork boluses and prey available in natural and created wetlands (ANOSIM Global $R=0.67, P=0.001$; Fig. 1a). Prey composition 
Fig. 1 (a) NMDS ordination of prey biomass depicting prey composition of stork boluses collected in urban and natural wetland colonies, prey available in natural wetlands, and prey available in ephemeral and permanently inundated created wetlands, South Florida, 20142017. (b) Biomass of nonnative fish are superimposed on the samples to indicate the relative biomass of nonnative prey in boluses, and in natural and created wetlands, South Florida, 2014-2017. (c)

Biomass of large-bodied fish are superimposed on the samples to indicate the relative biomass of large-bodied prey in boluses and created and natural wetlands,

South Florida, 2014-2017.

Larger circles indicate samples of relatively more biomass of large-bodied prey
* Natural wetland

$\Delta$ Urban bolus

2D Stress: 0.19

A Natural wetland bolus

- Permanently inundated created wetland

$\square$ Ephemeral created wetland

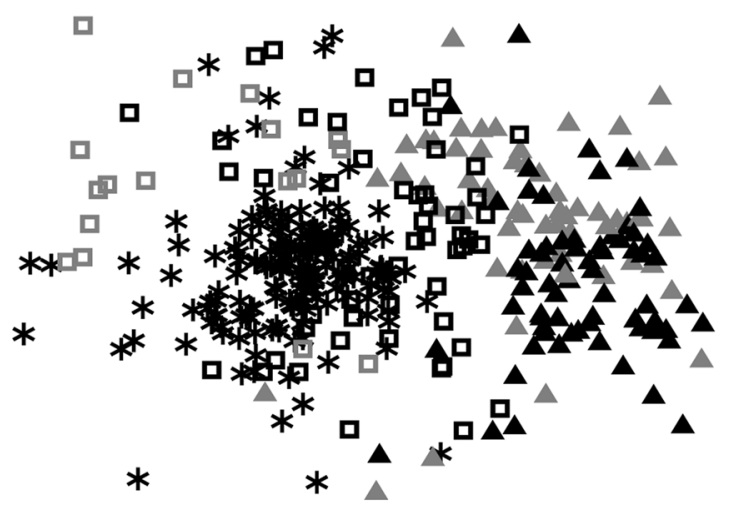

a

Natural wetland

Urban bolus

Natural wetland bolus

Created wetland

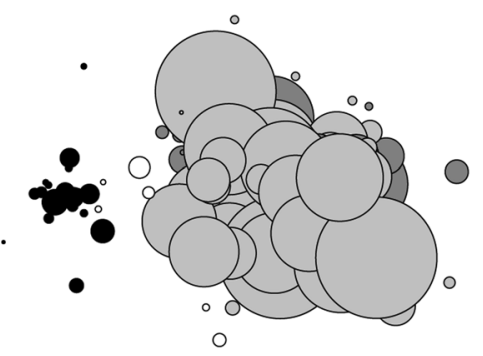

b

Natural wetland

Urban bolus

Natural wetland bolus

Created wetland 
was most dissimilar between stork boluses and natural wetlands (ANOSIM $R=0.75, P=0.001$ ). The high occurrence of grass shrimp and bluefin killifish within natural wetlands was responsible for most of the dissimilarity between natural wetland prey availability and stork boluses. Stork boluses were most similar to prey available in created wetlands with moderate differences ( $A N O S I M R=0.43, P=0.001)$. Stork boluses were most similar to permanently inundated created wetlands $(A N O S I M R=0.46$, $P=0.001)$ than to ephemeral created wetlands (ANOSIM $R=$ $0.77, P=0.001$ ). Additionally, boluses collected from urban colonies were most similar to samples from permanently inundated created wetlands with minor differences (ANOSIM $R=0.38, P$ $=0.001)$. The majority of the dissimilarity between prey composition of natural wetland and stork boluses was driven by the dominance of large-bodied (Fig. 1b) and nonnative prey (Fig. 1c). Additionally, prey lengths differed significantly between stork bolus samples and prey available in created and natural wetlands ( $\chi^{2}=12,565, P<0.001$; Supplementary Materials, Fig. S3). Prey found within stork boluses were significantly larger than prey available in created and natural wetlands, and prey in created wetlands were significantly larger than prey in natural wetlands (Supplementary Materials, Fig. S3).

Of the 753 boluses collected, 354 were from storks nesting in natural wetlands (hereafter referred to as "wetland storks") and 399 were from storks nesting in urban areas (hereafter referred to as "urban storks"). The low global $R$ statistic (ANOSIM Global $R=0.29, P=0.001$ ) suggested moderate prey composition differences between urban and wetland stork boluses (Fig. 2). Sunfish dominated boluses of both wetland and urban storks (Fig. 3a); however, sunfish species varied (Fig. 3b). Spotted sunfish contributed the most to the largebodied prey biomass of wetland storks whereas warmouth contributed the most to large-bodied prey biomass of urban storks. Similarly, the nonnative fish species consumed differed between urban and wetland storks (Fig. 3c). African jewelfish comprised the largest nonnative biomass in boluses of wetland storks (Fig. 3c), whereas blue tilapia (Oreochromis aureus) and Mayan cichlids contributed the most to overall nonnative prey biomass of urban storks (Fig. 3c). Additionally, fish present in boluses of wetland storks were significantly larger than boluses of urban storks ( $W=29,260, P<0.001)$.

Given the prey composition differences between urban and wetland storks, we examined where the different nonnative and large-bodied prey species occurred in created and natural wetland prey availability samples. African jewelfish were found in both created and natural wetlands (Fig. 4a) whereas Mayan cichlids were predominantly found in created wetlands (Fig. 4c). Blue tilapia and grass carp were not consistently

$\nabla$ Natural wetland bolus

2D Stress: 0.19

$\nabla$ Urban bolus

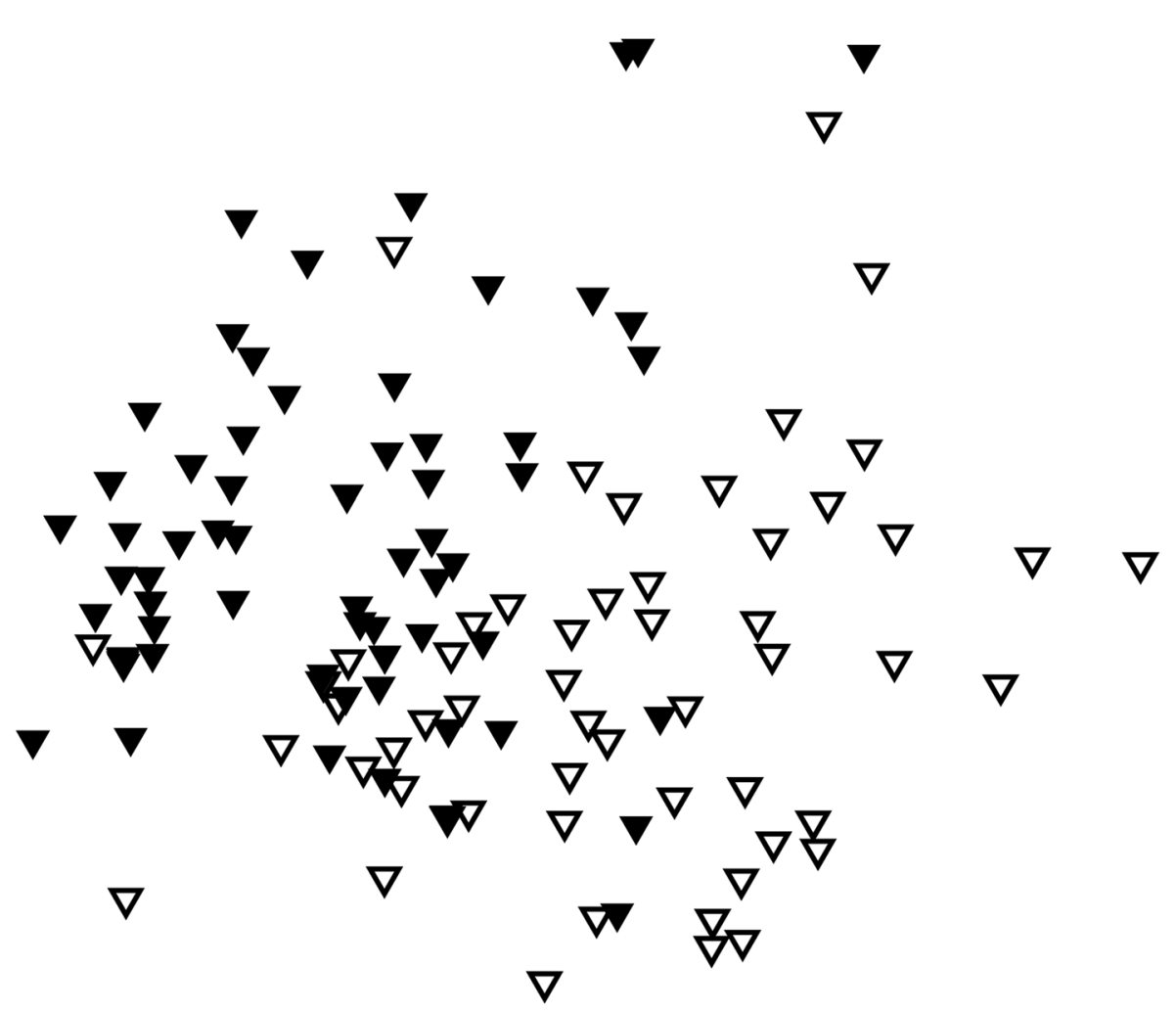

Global R: 0.29

Fig. 2 NMDS ordination of prey biomass depicting prey composition of urban and natural wetland storks, South Florida, 2014-2017 
Fig. 3 (a) Frequency of prey species within urban and wetland stork boluses, South Florida, 2014-2017. (b) Frequency of sunfish species within urban and wetland stork boluses,

South Florida, 2014-2017. (c)

Frequency of nonnative species within urban and wetland stork boluses, South Florida, 20142017
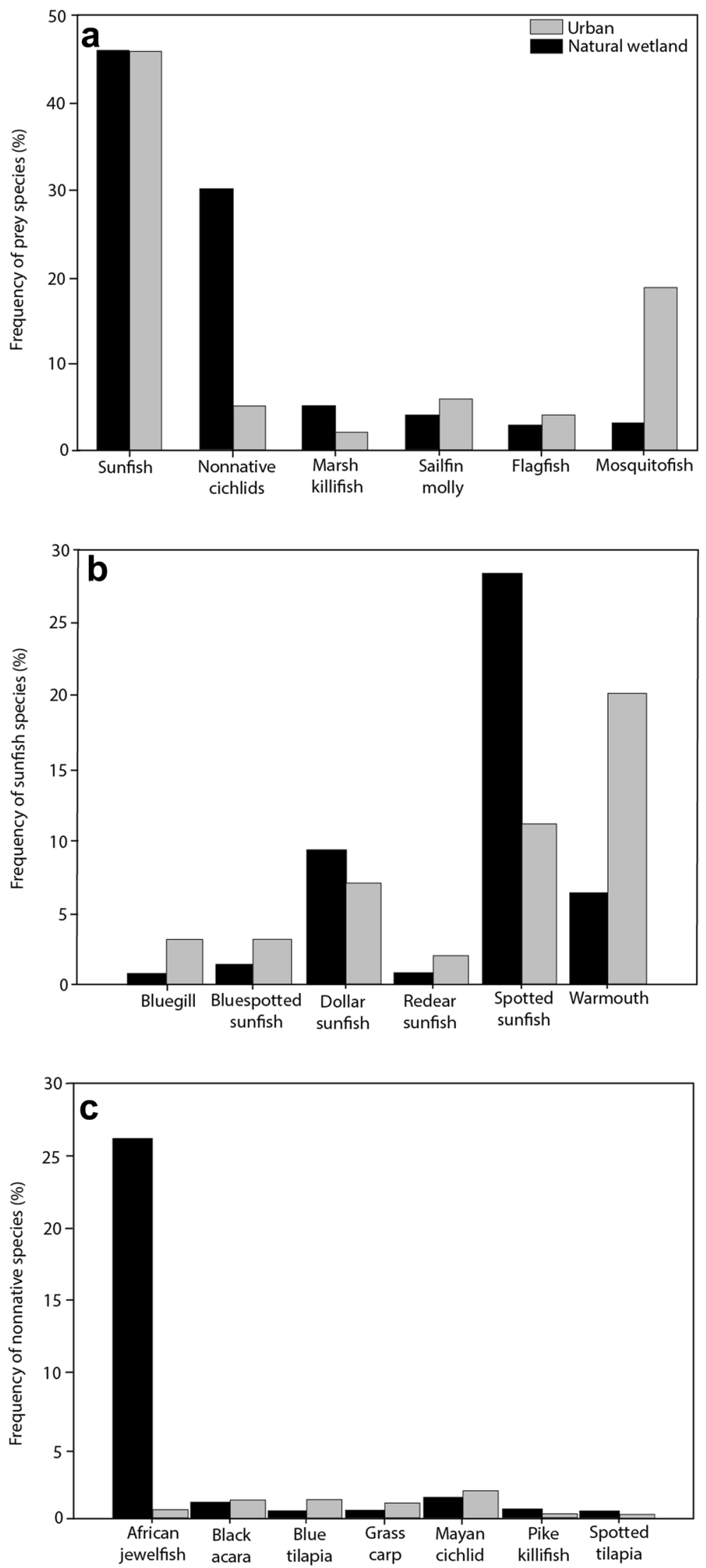


\section{Natural wetland \\ Urban bolus \\ Natural wetland bolus \\ Created wetland}

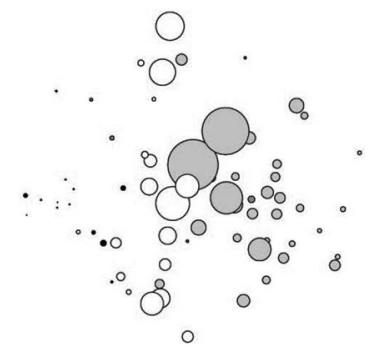

a

Natural wetland
Urban bolus
Natural wetland bolus
Created wetland

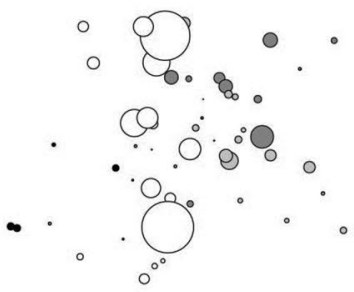

C

Fig. 4 (a) NMDS ordination of African jewelfish biomass in stork boluses, and in created and natural wetlands, South Florida, 20142017. (b) NMDS ordination of blue tilapia biomass in stork boluses, and in created and natural wetlands, South Florida, 2014-2017. (c) NMDS ordination of Mayan cichlid biomass in stork boluses, and in created and natural wetlands, South Florida, 2014-2017. (d) NMDS

present in either created or natural wetlands (Fig. 4b, d). For large-bodied prey, we found that spotted sunfish were more characteristic of the prey communities within natural wetlands, suggesting that wetland storks may be obtaining these prey from the natural wetlands (Fig. 5a). Furthermore, we found that warmouth were more characteristic of the prey communities within created wetlands, suggesting that urban storks may be obtaining these species from created wetlands (Fig. 5b).

\section{Discussion}

One of the challenges for large-bodied piscivores feeding in shallow wetlands that frequently dry and therefore favor small-bodied fish, is to find prey that are large enough to be energetically profitable. This is particularly true for birds, ordination of grass carp biomass in stork boluses, and in created and natural wetlands, South Florida, 2014-2017. Biomass of above nonnative species are superimposed on the samples to indicate the relative biomass of these species in boluses, and in created and natural wetlands. Larger circles indicate samples of relatively more biomass of specified nonnative species

such as storks that are active foragers. Mean prey length in the Everglades was only $2.2 \mathrm{~cm}$, so it was not surprising that storks in our study selected prey larger than what was available in the natural wetland landscape, which is consistent with earlier studies in South Florida (Ogden et al. 1976; Klassen and Gawlik 2018) and in other regions (Depkin et al. 1992; Ramo and Busto 1992; González 1997; Bryan and Gariboldi 1998).

More striking was the dramatic increase since the 1970s (Ogden et al. 1976) in proportion of nonnative fish in stork diets, first reported in Klassen and Gawlik (2018). Nonnative species comprised $<1 \%$ of prey composition in natural wetlands but now compose $15 \%$ of the fish biomass in stork diets. Furthermore, in 2016, wetland stork diet was dominated $(>60 \%)$ by nonnative fish. This pattern suggests storks had extremely strong selection for nonnative fish in natural 
Natural wetland samples

Urban bolus samples

Natural wetland bolus samples

Created wetland samples

a

Natural wetland samples

Urban bolus samples

Natural wetland bolus samples

Created wetland samples
2D Stress: 0.19

Global $R=0.67$
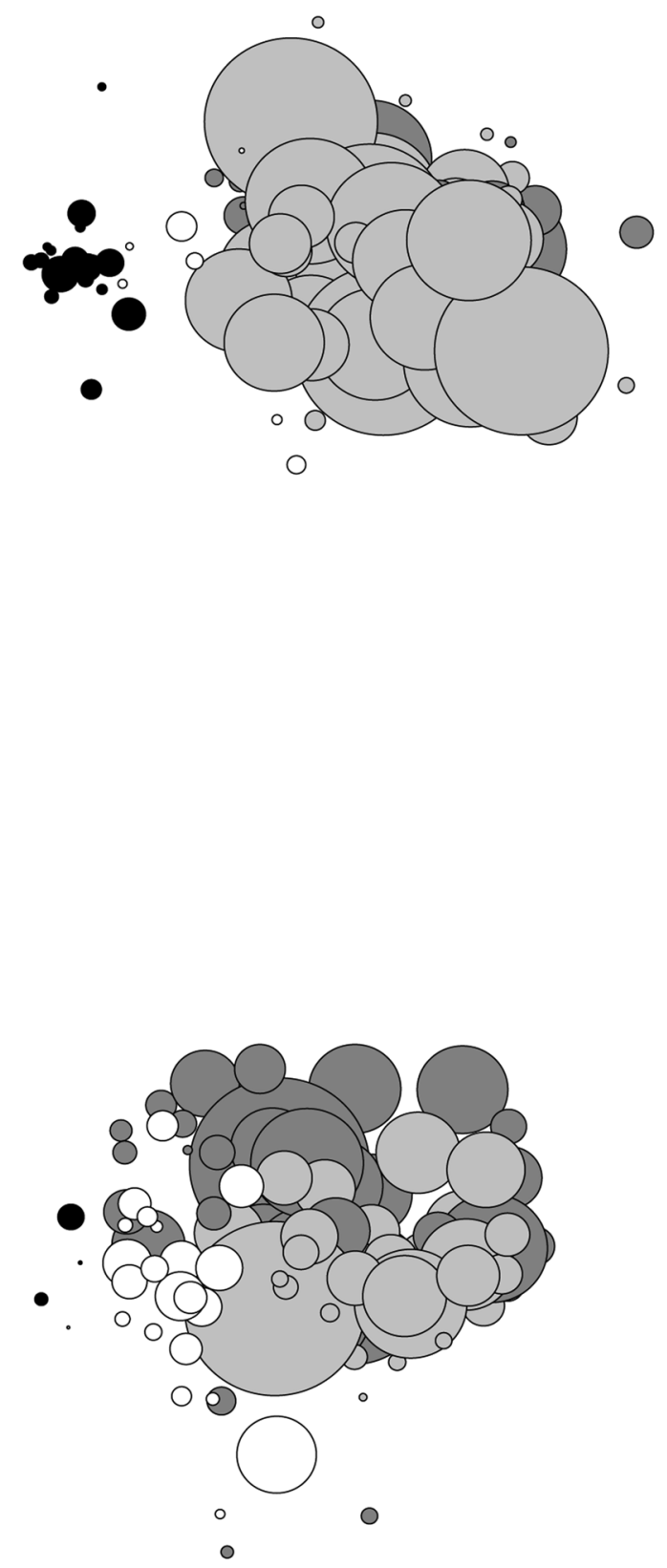

b 
4Fig. 5 (a) NMDS ordination of spotted sunfish biomass in stork boluses, and in created and natural wetlands, South Florida, 20142017. (b) NMDS ordination of warmouth biomass in stork boluses, and in created and natural wetlands, South Florida, 2014-2017. Biomass of spotted sunfish and warmouth are superimposed on the samples to indicate the relative biomass of sunfish and warmouth in boluses, and in created and natural wetlands. Larger circles indicate samples of relatively more biomass of spotted sunfish and warmouth

wetlands or that they were taking nonnative fish in other habitats. We also considered the alternate hypothesis that the apparent selectivity for nonnative fish was an artifact of sampling bias. However, in a test of bias between our two sampling methods (throw traps and minnow traps) at 10 sites, we found no difference in the prey composition, suggesting that sampling gear bias is not a likely explanation for the recent increase in consumption of nonnative fishes by storks.

There is some support for the hypothesis that the increase in proportion of nonnative fish in stork diets is because of the increase in anthropogenic deep-water habitats in the landscape. The vast system of canals throughout the Everglades has facilitated the spread of nonnative fish from the urban landscape into the natural wetland system (Shafland et al. 2008; Kline et al. 2014). We found that the prey available in created wetlands was dominated by both large-bodied and nonnative species similar to the species storks consumed. Permanently inundated features, such as large ponds and canals had a higher abundance of nonnative and large-bodied species than did ephemeral created wetlands (i.e. swales and ephemeral ponds). Canals in particular were dominated by large-bodied and nonnative fish species because of deep water and warmer temperatures, providing refugia during drought and cold stress conditions (Shafland and Pestrak 1982; Loftus and Kushlan 1987; Trexler et al. 2000; Rehage and Trexler 2006). Furthermore, we often observed storks foraging along roadways in created wetlands (Gawlik et al. 2017), supporting the hypothesis that large-bodied and nonnative prey found within stork boluses are from created wetlands.

Given the proximity of urban colonies to created wetlands, we expected that urban storks would have a higher proportion of large nonnative prey species in their diet than did wetland storks. However, the opposite was true. This was because the nonnative fish in the diets of wetland storks were mostly comprised of the African jewelfish (97\% of nonnatives in Paurotis Pond, 73\% of nonnatives in Tamiami West), a particularly successful invader in the coastal regions of the natural wetland system (Shafland et al. 2008; Langston et al. 2010; Kline et al. 2014). In contrast, the portion of nonnative fish in the diet of urban storks was distributed across more species, and those species were commonly found in urban areas.

We also observed differences in the species of native large-bodied fish consumed by urban and wetland storks.
Wetland storks primarily consumed spotted sunfish, which were most prevalent in natural wetlands. Urban storks consumed more warmouth, which were most prevalent in created wetlands. This pattern suggests that storks may be taking these species in proximity to their nesting sites. A key knowledge gap is the extent to which storks from both types of colonies rely on natural and created wetlands during the breeding season.

Urban and wetland storks also differed based on the proportion of native, small-bodied fish in their diets. Urban storks consumed a higher proportion of native, small-bodied fish species, driving the smaller prey length distribution observed in the urban stork diet. It is unclear if urban storks are consuming these small-bodied fish from created or natural wetlands. It is important to note that all urban stork colonies were located within $10 \mathrm{~km}$ of the natural wetland system, well within the 74-km foraging radii for storks. Given the proximity of the urban system to the natural wetland system, urban storks have the benefit of foraging in natural wetlands when hydrologic conditions are good and using urban habitats as a buffer when conditions in the natural wetlands are poor (Evans and Gawlik 2020).

Not only did urban storks include different prey species in their diet, but urban storks also consumed human refuse, comprising 3\% of the overall biomass. The use of human refuse is an increasingly common foraging strategy for many bird species (Tortosa et al. 2002; Dorn et al. 2011; Gilbert et al. 2016; Plaza and Lambertucci 2017). Moreover, storks in our study use human refuse more frequently when natural wetland conditions are suboptimal (Evans and Gawlik 2020). Whereas it is not clear if storks are obtaining these food items from garbage receptacles, landfills, or they are being fed intentionally by humans, it does provide evidence of further dietary flexibility of the species.

Overall, the results of our study suggest that storks have some form of behavioral plasticity in the choice of both foraging habitat and prey species in response to HIREC. Behavioral plasticity is also the likely mechanism that produced a relatively smaller drop in productivity for urban storks than storks nesting in natural wetlands when hydrologic conditions were poor (Evans and Gawlik 2020). In poor hydrologic years, when prey are not effectively concentrated by fluctuating water levels, storks may rely on created wetlands as they are more predictable because they rarely dry. However, it is important to note that other consequences of using these novel environments are unknown. Created wetlands may provide storks with more predictable food sources; however, these wetlands are frequently located within urban areas with intense anthropogenic activity (Tuomainen and Candolin 2011). Many of the created wetlands observed in this study were subject to frequent disturbance which may lead to an alteration in prey communities or accessibility to storks. Although our study did not quantify the degree 
to which storks depend on created wetlands, the patterns of diet we documented suggest that created wetlands are likely important foraging areas for storks, and therefore should be considered in the management of the species.

The Wood Stork is just one example of a recent global increase in the use in anthropogenic resources by storks and other wetland bird species, possibly as a mechanism for coping with widespread impacts to wetlands around the world. In Europe, White Storks (Ciconia ciconia) were nearly extinct in the mid-1970s; however, the population has increased, and many have stopped migrating because of predictable anthropogenic food sources (Tortosa et al. 2002; Massemin-Challet et al. 2006; Gilbert et al. 2016). Similarly, both Marabou Storks (Leptoptilos crumenifer) and Woolly-necked Storks (Ciconia microscelis) have begun to consume predictable anthropogenic food sources in parts of their range (Pomeroy and Kibuule 2017; Thabethe and Downs 2018; Francis et al 2021). There are also other waterbird species that have responded to the introduction of novel prey items. Grey Herons (Ardea cinerea) have increased foraging and breeding because of the expansion of the introduced round goby (Neogobius melanostomus) in the Baltic Sea (Jakubas 2004). In Florida, the Everglade Snail Kite (Rostrhamus sociabilis plumbeus) has recently switched from consuming predominantly native apple snails to nonnative apple snail species (Reichert et al. 2011; Cattau et al. 2016). Whereas a switch in diet initially may benefit a population, it could also mask impacts. For example, Double-crested Cormorants (Phalacrocorax auritus) recently switched diets to include the nonnative round goby, which has less nutritional value than native prey (Van Guilder and Seefelt 2013).

Considering that so many avian species are exhibiting dietary shifts in response to HIREC, the relationship between HIREC and diet should be considered in the conservation efforts of many species, particularly those that are food limited. As natural wetlands continue to be degraded and lost, wetland birds will continue to be impacted unless they can exploit novel environments, such as created wetlands, the only category of wetland that increased in the latest assessment of wetland trends (Dahl 2011). Although novel habitats such as urban wetlands may pose risks, the importance of novel prey and foraging habitats to species that exist in both natural and urban habitats could be critical in sustaining populations in the face of a rapidly changing planet.

Supplementary information The online version contains supplementary material available at https://doi.org/10.1007/s11252-021-01181-9.

Acknowledgements We are grateful to the many individuals who provided substantial assistance in the field, including Lauren Haag, Jenna May, Carl Santangelo, Victor Benavides, Alissa Gulette, Sarah Staton, Zara Mansoor, and Ashley Jackson. We also thank Wendy Cyriacks and Andrew Gottlieb, for their assistance in project management and field data collection. We are also grateful to Rindy Anderson, Nathan Dorn, Colin Hughes, Kate Shlepr, and two anonymous reviewers for invaluable comments on drafts of this manuscript.
Author contributions Betsy Evans, Jessica Klassen, and Dale Gawlik designed the study and developed the methods. Betsy Evans and Jessica Klassen collected the data. Betsy Evans analyzed the data and wrote the manuscript. Dale Gawlik and Jessica Klassen provided substantial feedback and edited all versions of the manuscript.

Funding This research was supported by the Florida Department of Transportation (BDV27-922-02).

Availability of data and material All data are available upon request.

Code availability Primary analyses were done using a non-code-based software, PRIMER-7. Information on these analyses are available by request.

\section{Declarations}

Ethics approval Research techniques were approved by the Florida Atlantic University Institutional Animal Care and Use Committee (IACUC; Protocol A14-11, A14-28), US Fish and Wildlife Service (TE65550A), Big Cypress National Preserve (BICY-2014-SCI-0014), Everglades National Park (EVER-2014/2016-SCI-0021), Florida Fish and Wildlife Conservation Commission (S-15-02), and the Miccosukee Tribe of Indians of Florida.

Consent to participate Not applicable.

Conflict of interest/competing interests The authors declare no conflict of interest or competing interests.

\section{References}

Baronsky AD, Matzke N, Tomiya S, Wogan GOU, Swartz B, Quental TB, Marshall C, McGuire JL, Lindsey EL, Maguire KC, Mersey B, Ferrer EA (2011) Has the Earth's six mass extinction already arrived? Nature 471:51-57. https://doi.org/10.1038/nature09678

Borkhataria RR, Frederick PC, Keller RA, Collazo JA (2012) Temporal variation in local wetland hydrology influences postdispersal survival of juvenile Wood Storks (Mycteria americana). Auk 129:517-528. https://doi.org/10.1525/auk.2012.11244

Botson BA, Gawlik DE, Trexler JC (2016) Mechanisms that generate resource pulses in a fluctuating wetland. PLoS One 11:e0158864. https://doi.org/10.1371/journal.pone.0158864

Brousseau P, Lefebvre J, Giroux JF (1996) Diet of ring-billed gull chicks in urban and non-urban colonies in Quebec. Col Waterbirds 19:22-30. https://doi.org/10.2307/1521803

Bryan AL Jr, Gariboldi JC (1998) Food of nestling Wood Storks in coastal Georgia. Col Waterbirds 21:152-158. https://doi.org/10. 2307/1521902

Cattau CE, Fletcher RJ Jr, Reichert BE, Kitchens WM (2016) Counteracting effects on a nonnative prey on the demography of a native predator culminate in positive population growth. Ecol Appl 26:1952-1968. https://doi.org/10.1890/15-1020.1

Chao A, Gotelli NJ, Hsieh TC, Sander EL, Ma KH, Colwell RK, Ellison AM (2014) Rarefaction and extrapolation with Hill numbers: a framework for sampling and estimation in species diversity studies. Ecol Monogr 84:45-67. https://doi.org/10.1890/13-0133.1

Clarke KR, Gorley RN (2015) Plymouth routines in multivariate ecological research. Getting started with PRIMER 7. http://updates.primere.com/primer7/manuals/Getting_started_with_PRIMER_7.pdf

Clarke KR, Green RH (1988) Statistical design and analysis for 'biological effects' study. Mar Ecol Prog Ser 46:213-226. https://doi. org/10.3354/meps046213 
Cowell RK, Chao A, Gotelli NJ, Lin SY, Mao CX, Chazdon RL, Longino JT (2012) Models and estimators linking individual-based and samplebased rarefaction, extrapolation and comparison of assemblages. Plant Ecol 5:3-21. https://doi.org/10.1093/jpe/rtr044

Dahl TE (2011) Status and trends of wetlands in the conterminous United States 2004 to 2009. Department of the Interior, US Fish and Wildlife Service, Washington, DC, USA

DeAngelis DL, Trexler JC, Cosner C, Obaza A, Jopp F (2010) Fish population dynamics in a seasonally varying wetland. Ecol Modell 221:1131-1137. https://doi.org/10.1016/j.ecolmodel.2009.12.021

Depkin FC, Coulter MC, Bryan AL Jr (1992) Food of nestling Wood Storks in east-central Georgia. Col Waterbirds 15:219-225. https://doi.org/10.2307/1521455

Dorn NJ, Cook MI, Herring G, Boyle RA, Nelson J, Gawlik DE (2011) Aquatic prey switching and urban foraging by the White Ibis Eudocimus albus are determined by wetland hydrological conditions. Ibis 153:323-335. https://doi.org/10.1111/j.1474-919X. 2011.01101.x

Evans BA, Gawlik DE (2020) Urban food subsidies reduce natural food limitations and reproductive costs for a wetland bird. Sci Rep 10:14021. https://doi.org/10.1038/s41598-020-70934-x

Fidorra JC, Frederick PC, Evers DC, Meyer KD (2016) Selection of human-influenced and natural wetlands by Great Egrets at multiple scales in the southeastern USA. Condor 118:46-56. https:// doi.org/10.1650/CONDOR-14-117.1

Francis RJ, Kingsford RT, Murray-Hudson M, Brandis KJ (2021) Urban waste no replacement for natural foods-Marabou storks in Botswana. J Urban Ecol 7:1-10. https://doi.org/10.1093/jue/ juab003

Frederick PC, Gawlik DE, Ogden JC, Cook MI, Lusk M (2009) The white ibis and wood stork as indicators for restoration of the Everglades system. Ecol Indic 9:S83-S95. https://doi.org/10.1016/j.ecolind.2008. 10.012

Frederick PC, Spalding MG (1994) Factors affecting reproductive success of wading birds (Ciconiiformes) in the Everglades ecosystem. In: Davis SM, Ogden JC (eds) Everglades: The ecosystem and its restoration St. Lucie Press, Delray Beach, Florida, pp 659-692

Gawlik DE (2000) South Florida wading bird report. South Florida Water Management District, West Palm Beach, Florida

Gawlik DE (2002) The effects of prey availability on the numerical response of wading birds. Ecol Monogr 72:329-346. https://doi. org/10.1890/0012-9615(2002)072[0329:TEOPAO]2.0.CO;2

Gawlik DE, Evans BA, Klassen JA, Gottlieb A, Cyriacks W (2017) Wood Stork use of roadway corridor features in South Florida. Report to the Florida Department of Transportation, Fort Lauderdale, Florida

Gienapp P (2012) Migration. In: Wong BBM, Candolin U (eds) Behavioural responses to a changing world. Oxford University Press, Oxford, pp 80-92

Gilbert NI, Correia RA, Silva JP, Pacheco C, Catry I, Atkinson PW, Gill JA, Franco AMA (2016) Are white storks addicted to junk food? Impacts of landfill use on the movement and behavior of resident white storks (Ciconia ciconia) from a partially migratory population. Mov Ecol 4:7. https://doi.org/10.1186/s40462-016-0070-0

González J (1997) Seasonal variation in the foraging ecology of the Wood Stork in the southern llanos of Venezuela. Condor 99:671680. https://doi.org/10.2307/1370479

Grémillet D, Pichegru L, Kuntz G, Woakes AG, Wilkinson S, Crawford RJM, Ryan PG (2008) A junk-food hypothesis for gannets feeding on fishery waste. Proc R Soc B 275:1149-1156. https://doi.org/ 10.1098/rspb.2007.1763

Gunderson LH, Loftus WF (1993) The Everglades. In: (Martin WH, Boyce SG, Echternact AC (eds) Biodiversity of the Southeastern United States: lowland terrestrial communities Wiley, New York, pp 199-255
Herring HK, Gawlik DE (2011) Resource selection functions for Wood Stork foraging habitat in the southern Everglades. Waterbirds 34:133-142. https://doi.org/10.1675/063.034.0201

Hsieh TC, Ma KH, Chao A (2016) iNEXT: iNterpolation and EXTrapolation for species diversity. R package 2.0.12. http://chao.stat. nthu.edu.tw/blog/software-download/. Accessed 16 June 2018

Ishiyama N, Sueyoshi M, Watanabe N, Nakamura F (2016) Biodiversity and rarity distributions of native freshwater fish in an agricultural landscape: the importance of $\beta$ diversity between and within water-body types. Aquat Conserv 26:416-428. https://doi.org/10. $1002 /$ aqc. 2583

Jakubas D (2004) The response of the grey heron to a rapid increase of the Round Goby. Waterbirds 27:304-307. https://doi.org/10.1675/ 1524-4695(2004)027[0304:TROTGH]2.0.CO;2

Jordan F, Coyne S, Trexler JC (1997) Sampling fishes in vegetated habitats: effects of habitat structure on sampling characteristics in the $1-\mathrm{m}^{2}$ throw trap. T Am Fish Soc 126:1012-1020. https://doi.org/10.1577/ 1548-8659(1997)126\%3c1012:SFIVHE\%3e2.3.CO;2

Kahl MP Jr (1964) Food ecology of the wood stork (Mycteria americana) in Florida. Ecol Monogr 34:97-117. https://doi.org/10. 2307/1948449

King RS, Richardson CJ, Urban DL, Romanowicz EA (2004) Spatial dependency of vegetation-environment linkages in an anthropogenically influenced wetland ecosystem. Ecosystems 7:75-97

Klassen JA, Gawlik DE (2018) Changing diets as a means to predict species adaptability to human-induced rapid environmental change. J Field Ornithol 89:126-139

Kline JL, Loftus WF, Kotun K, Trexler JC, Rehage JS, Lorenz JJ, Robinson M (2014) Recent fish introductions into Everglades National Park: an unforeseen consequence of water management? Wetlands 34:175-187. https://doi.org/10.1007/ s13157-012-0362-0

Kushlan JA (1976) Wading bird predation in a seasonally fluctuating pond. Auk 93:464-476

Lack D (1954) The natural regulation of animal numbers. Oxford University Press, Oxford

Langston JN, Schofield PJ, Hill JE, Loftus WF (2010) Salinity tolerance of the African jewelfish Hemichromis letourneuxi, a nonnative cichlid in South Florida USA. Copeia 3:475-480. https://doi. org/10.1643/CP-09-069

Loftus WF, Kushlan JA (1987) Freshwater fishes of southern Florida. Bull Fla State Mus Biol Sci 31:147-344

Lopéz-Sepulcre A, Kokko H (2012) Understanding behavioural responses and their consequences. In: Wong BBM, Candolin U (eds) Behavioural responses to a changing world. Oxford University Press, Oxford, pp 3-15

Massemin-Challet S, Gendner JP, Samtmann S, Pichegru L, Wulgué A, Maho YL (2006) The effect of migration strategy and food availability on White Stork Ciconia ciconia breeding success. Ibis 148:503-508. https://doi.org/10.1111/j.1474-919X.2006.00550.x

Nuttle WK (1997) Measurement of wetland hydroperiod using harmonic analysis. Wetlands 17:82-89. https://doi.org/10.1007/ BF03160720

Oaks JL, Gilbert M, Virani MZ, Watson RT, Meteyer CU, Rideout BA, Shivaprasad HL, Ahmed S, Chaudhry MJI, Arshad M, Mahmood S, Ali A, Khan AA (2004) Diclofenac residues as the cause of vulture population decline in Pakistan. Nature 427:630-633. https:// doi.org/10.1038/nature02317

Ogden JC, Kushlan JA, Tilmant JT (1976) Prey selectivity by the wood stork. Condor 78:324-330. https://doi.org/10.2307/1367691

Ogden JC (1994) A comparison of wading bird nesting dynamics, 1931-1946 and 1974-1989 as an indication of changes in ecosystem conditions in the southern Everglades. In: Davis S, Ogden JC (eds) Everglades: The Ecosystem and its Restoration St. Lucie Press, Delray Beach, Florida, pp 533-570 
Palumbi SR (2001) Humans as the world's greatest evolutionary force. Science 293:1786-1790. https://doi.org/10.1126/science.293. 5536.1786

Plaza PI, Lambertucci SA (2017) How are garbage dumps impacting vertebrate demography, health, and conservation? Glob Ecol Conserv 12:9-20. https://doi.org/10.1016/j.gecco.2017.08.002

Pomeroy D, Kibuule M (2017) Increasingly urban Marabou Storks start breeding four months early in Kampala, Uganda. Ostrich 88:261-266. https://doi.org/10.2989/00306525.2017.1308443

R Development Core Team (2017) R: A language and environment for statistical computing. R 3.2.4. Vienna, Austria: R Foundation for Statistical Computing

Ramo C, Busto B (1992) Nesting failure of the Wood Stork in a neotropical wetland. Condor 94:777-781. https://doi.org/10.2307/ 1369265

Rehage JS, Trexler JC (2006) Assessing the net effect of anthropogenic disturbance on aquatic communities in wetlands: community structure relative to distance form canals. Hydrobiologia 569:359-373. https://doi.org/10.1007/s10750-006-0142-Z

Reichert B, Cattau C, Kitchens W, Fletcher R, Olbert J, Pias K, Zweig C (2011) Snail Kite Demography annual report 2011. Interim Report to the U.S. Army Corps of Engineers, Jacksonville, Florida

Rodgers JA Jr, Smith HT (1995) Set-Back Distances to Protect Nesting Bird Colonies from Human Disturbance in Florida. Conserv Biol 9:89-99. https://doi.org/10.1046/j.1523-1739.1995.09010089.x

Rodgers JA Jr, Schwikert ST (2002) Buffer-zone distances to protect foraging and loafing waterbirds from disturbance by personal watercraft and outboard-powered boats. Conserv Biol 16:216-224

Rosenthal GG, Stuart-Fox D (2012) Environmental disturbance and animal communication. In: Wong BBM Candolin U (eds) Behavioural responses to a changing world. Oxford University Press, Oxford, pp 16-31

Ruffino L, Salo P, Koivisto E, Banks PB, Korpimäk E (2014) Reproductive responses of birds to experimental food supplementation: a meta-analysis. Front Zoo 11:80. https://doi.org/10.1186/ s12983-014-0080-y

Schofield PJ, Loftus WF, Kobza RM, Cook MI, Sloane DH (2010) Tolerance of nonindigenous cichlid fishes (Cichlasoma urophthalmus, Hemichromis letourneuxi) to low temperature: laboratory and field experiments in South Florida. Biol Invasions 12:22412457. https://doi.org/10.1007/s10530-009-9654-6

Shafland PL, Pestrak JM (1982) Lower lethal temperatures for fourteen nonnative fishes in Florida. Environ Biol Fishes 7:149-156. https://doi.org/10.1007/BF00001785

Shafland P, Gestring KB, Stanford MS (2008) Florida's exotic freshwater fishes-2007. Florida Scientist 71:220-245

Sih A, Ferrari MCO, Harris DJ (2011) Evolution and behavioural responses to human-induced rapid environmental change. Evol Appl 3:367-387. https://doi.org/10.1111/j.1752-4571.2010. 00166.x
Sih A (2013) Understanding variation in behavioural responses to human-induced rapid environmental change: a conceptual overview. Anim Behav 85:1077-1088. https://doi.org/10.1016/j. anbehav.2013.02.017

Snell-Rood EC (2013) An overview of evolutionary causes and consequences of behavioural plasticity. Anim Behav 85:1004-1011. https://doi.org/10.1016/j.anbehav.2012.12.031

Sol D, Lapiedra O, Gonzalez-Lagos C (2013) Behavioural flexibility for life in the city. Anim Behav 85:1101-1112

Thabethe V, Downs CT (2018) Citizen science reveals widespread supplemental feeding of African woolly-necked storks in suburban areas of KwaZulu-Natal, South Africa. Urban Ecosyt 21:965-973. https:// doi.org/10.1007/s11252-018-0774-6

Tortosa FS, Caballero JM, Reyes-López J (2002) Effect of rubbish dumps on breeding success in the White Stork in Southern Spain. Waterbirds 25:39-43. https://doi.org/10.1675/1524-4695(2002) 025[0039:EORDOB]2.0.CO;2

Trexler JC, Loftus WF, Jordan F, Lorenz JJ, Chick JH, Kobza RM (2000) Empirical assessment of fish introduction in a subtropical wetland: an evaluation of contrasting views. Biol Invasions 2:265-277. https://doi.org/10.1023/A:1011488118444

Tuomainen U, Candolin U (2011) Behavioural responses to humaninduced environmental change. Biol Rev Camb Philos Soc 86:640-657

United States Fish and Wildlife Service (USFWS) (1996) Revised recovery plan for the U.S. breeding population of the wood stork. U. S. Fish and Wildlife Service. Atlanta, Georgia, p 41

United States Fish and Wildlife Service (USFWS) (2014) Reclassification of the U.S. breeding population of the Wood Stork from endangered to threatened. Federal Register 79:37078-37103

United States Fish and Wildlife Service (USFWS) (2015) Wood Stork Southeast US Nesting from 1975 to 2015. U.S. Fish and Wildlife North Florida Ecological Services Office. https://www.fws.gov/ northflorida/woodstorks/wood-storks.htm. Accessed 17 Jun 2018

Van Guilder MA, Seefelt NE (2013) Double-crested Cormorant (Phalacrocorax auritus) chick bioenergetics following round goby (Neogobius melanostomus) invasion and implementation of cormorant population control. J Great Lakes Res 39:153-161. https://doi.org/10.1016/j.jglr.2012.12.019

Van Houtan KS, Pimm SL, Halley JM, Bierregaard RO, Lovejoy TE (2007) Dispersal of Amazonian birds in continuous and fragmented forest. Ecol Lett 10:219-229. https://doi.org/10.1111/j. 1461-0248.2007.01004.x

Williams SE, Shoo LP, Isaac JL, Hoffmann AA, Langham G (2008) Towards an integrated framework for assessing the vulnerability of species to climate change. PLoS Biol 6:26212626. https://doi. org/10.1371/journal.pbio.0060325

Wong BBM, Candolin U (2015) Behavioral responses to changing environments. Behav Ecol 26:665-673. https://doi.org/10.1093/ beheco/aru183 